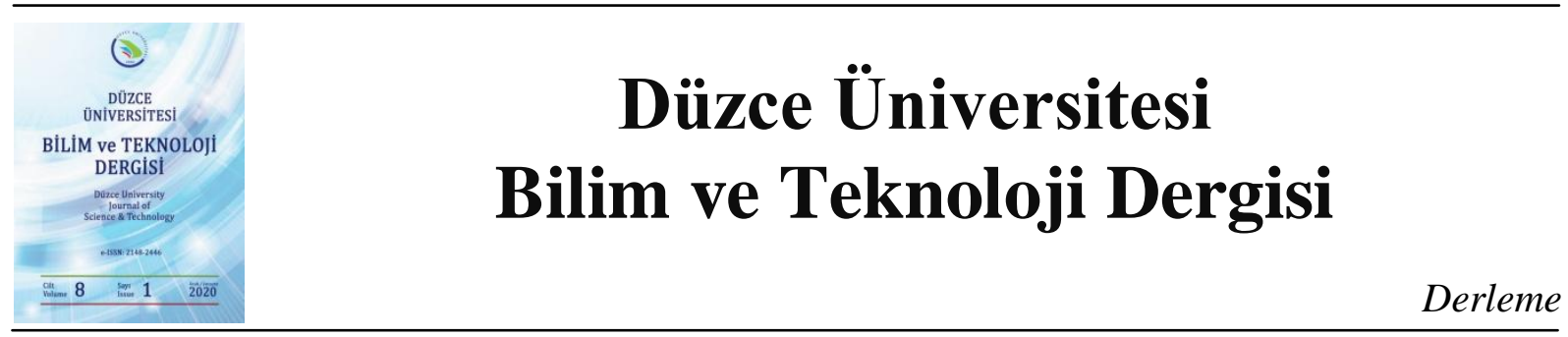

\section{Orman Ürünleri Sanayindeki Davranışsal Strateji Çalışmaları Üzerine Bir Derleme}

\author{
Hasan SERİN $^{\mathrm{a}}$, (iD Muhammet DURGUN ${ }^{\mathrm{b}, *}$, (iD Sadegül DURGUN ${ }^{\mathrm{c}}$ \\ ${ }^{a}$ Orman Endüstri Mühendisliği Bölümü, Orman Fakültesi, Kahramanmaraş Sütçü İmam Üniversitesi, \\ Kahramanmaraş, TÜRKIYE \\ ${ }^{b}$ Orman Endüstri Mühendisliği Bölümü, Fen Bilimleri Enstitüsü, Kahramanmaraş Sütçü İmam Üniversitesi, \\ Kahramanmaraş, TÜRKIYE \\ ${ }^{c}$ Kamu Yönetimi Bölümü, İktisadi ve İdari Bilimler Fakültesi, Kahramanmaraş Sütçü İmam Üniversitesi, \\ Kahramanmaraş, TÜRKIYE \\ * Sorumlu yazarin e-posta adresi: muhammetdurgunksu@ gmail.com
}

DOI: $10.29130 /$ dubited.642464

\begin{abstract}
ÖZET
Firma heterojenliği üzerine kurulu olan stratejik yönetim alanında rasyonelliği başa koyan ekonomik yaklaşımlar her zaman baskın rolde olmuşlardır. Bununla birlikte firmaların bazı stratejik durumlarda bu yaklaşımların öngördüğü şekilde hareket etmemeleri, farklı bir yaklaşımın gerekliliğini göstermiştir. Davranışsal strateji olarak adlandırılan bu yaklaşım, temelde insanların sınırlı rasyonellik sergiledikleri olgusuna dayanarak stratejik yönetim teori ve uygulamalarının psikolojik ve gerçekçi temellerini ortaya koymayı amaçlamaktadır. Stratejik yönetim disiplininin bu alt alanı bu yönüyle, son yıllarda araştırmacıların ilgisini muazzam derecede çekmeyi başarmıştır.

Çeşitli sektör ve örgütlerde araştırma konusu yapılan davranışsal strateji çalışmaları orman ürünleri sanayinde de görülmektedir. Bu makalede orman ürünleri sanayindeki davranışsal strateji çalışmaları derlenmiştir. Makalenin ilk bölümünde davranışsal stratejiye yönelik çeşitli görüşlere yer verilmiştir. Ardından indirgemeci, çoğulcu ve bağlamsalcı şeklinde üçlü sınıflandırmayla orman ürünleri sanayinde yapılmış çalışmalar incelenmiş̧ir. Son olarak ise orman endüstri işletmeciliğindeki davranışsal strateji çalışmalarına yönelik bazı öneriler ile makale sonlandırılmıştır.
\end{abstract}

Anahtar Kelimeler: Davranışsal strateji, Psikoloji, Biliş, Orman ürünleri sanayi

\section{A Review on Behavioral Strategy Studies within Forest Products Industry}

\begin{abstract}
In strategic management field based on firm heterogeneity, economic approaches adopting rationality have always been at dominant roles. However, the fact firms do not act in some strategic situations in a way predicted by these approaches show requirement of a different approach. Based basically on the truth that people exhibit bounded rationality, this approach called as behavioral strategy aims to present psychological and realistic grounds of strategic management theory and practices. In this aspect this subfield of strategic management discipline has achieved to attract attention of researchers tremendously in recent years.
\end{abstract}

There are behavioral strategy studies within forest products industry that have been research subject in various sectors and organization types. In this article behavioral strategy studies within forest products industry have 
been reviewed. In first section of article different perspectives on behavioral strategy have been revealed. Following, with a triple classification such as reductionist, pluralist and contextualist, studies done within forest products industry have been examined. Lastly, article has been concluded with some suggestions for behavioral strategy studies in forest products business administration.

Keywords: Behavioral strategy, Psychology, Cognition, Forest products industry

\section{GIRIS}

Belli bir amacı yerine getirmek için faaliyetlerini sürdüren örgütler; ister kamu veya sivil toplum, isterse de özel sektör içerisinde yapılansın stratejik yönetim faaliyetlerini yapmak zorundadırlar. Strateji formüle etmek, uygulamak ve kontrolünü yapmak, örgütlerin belirledikleri amaçları gerçekleştirmek için gerekli olan stratejik yönetim sürecinin temel aşamalarıdır. Bu süreç her ne kadar rasyonel bir anlayışla uygulanmak istense de; bilişsel yanlılıklar, kestirme yollar, duygular, sosyal etkileşimler gibi insani özellikler nedeniyle çoğu kez rasyonellikten sapmalar görülmektedir. Bu ise örgütlerin hedefledikleri performans düzeylerine erişememeleri sonucunu doğurmaktadır. Bu nedenle de psikolojik temelli yaklaşımlar stratejik yönetim alanına girmiş ve son yıllarda davranışsal strateji adı altında bir alt alan oluşmuştur.

Bu makalede orman ürünleri sanayi baz alınarak yapılmış davranışsal strateji çalışmaları derlenmiştir. Öncelikle davranışsal stratejiye yönelik açıklamalara yer verilmiş, ardından indirgemeci, çoğulcu ve bağlamsalcı okul olmak üzere üç bölüm şeklinde orman ürünleri sanayindeki davranışsal strateji çalışmaları incelenmiştir. Sonuç bölümünde ise orman ürünleri işletmeciliği ile ilgili çeşitli öneriler sunulmuş ve çalışma sonlandırılmıştır.

\section{DAVRANISSSAL STRATEJI}

Stratejik yönetim üzerine, içerisinde farklı unsurlar barındıran, birçok tanım yapılmıştır. $\mathrm{Bu}$ tanımlardan birine göre stratejik yönetim; işletmelerin uzun dönemde yaşamını devam ettirebilme, sürdürülebilir rekabet üstünlüğü kazanabilme ve sonuç olarak faaliyette bulunulan sektörün ortalama kârı üzerinde getiri sağlayabilme amaçlarıyla, üretim kaynaklarını etkili ve verimli kullanmasıdır [1]. Nag, Hambrick ve Chen [2] tarafindan alanın önemli isimlerinden veri toplanarak oluşturulan bir tanıma göre ise; stratejik yönetim alanı, kaynakları kullanarak firmaların performansını arttırmak için firma sahipleri adına genel müdürler tarafından dış çevrede alınan amaçlı ve ortaya çıkan, önemli inisiyatiflerle uğraşmaktadır.

Tanımlarda ifade edilen haliyle yönetim ve örgüt çalışmalarının bir yönünü oluşturan stratejik yönetim (kimilerine göre örgütsel strateji veya sadece strateji), temel olarak işletmelerin neden farklı stratejiler ve yapılar benimsediklerini, rakip işletmelerin neden farklı performanslar sergilediklerini ve bu farklılığın neden devam ettiğini araştırmaktadır. Firma heterojenliği olarak adlandırılan bu önemli problem seti farklı stratejik yönetim teorilerinde farklı biçimlerde açıklanmaktadır. Kimileri monopoli engellerinin koruduğu piyasa gücünü [3], kimileri faktör kıtlığının koruduğu kaynak avantajlarını [4], kimileri ise girişimcilik ve teknolojinin hareket ettirdiği inovasyonu [5] firma heterojenliğini açıklamak için kullanmıştır. Bu teorilerin tamamı ekonomik rasyonelliği varsaymaktadırlar. Ancak son y1llarda Lehman Brothers, Bear Stearns ve BP gibi güçlü küresel şirketlerde görülen performans şokları ve iflaslar ile AOL/Time-Warner ve HP/Compaq gibi başarısızlıkla sonuçlanan şirket birleşmeleri bu teorilerin açıklayamadığı önemli strateji vakalarıdır. Yöneticilerin kötü ve yanlış kararlarının sebep olduğu bu vakalar, yukarıda bahsedilen açıklamalara yeni bir bakış açısı getiren ve stratejik yönetimin dördüncü sütunu olarak adlandırılan davranışsal strateji ile açıklanabilecektir [6]. Bununla beraber Bromiley ve Rau [7] stratejik yönetim araştırmalarının temelde iki büyük yaklaşımla ifade edildiğini belirtmektedir. İlki firma heterojenliğini değerli ve taklit edilemez kaynaklara yükleyen kaynak tabanlı görüş; diğeri ise rekabet koşullarına yükleyen endüstriyel ekonomi 
yaklaşımıdır. İki yaklaşım da örgütsel karar vericilerin hiper-rasyonellik sergilediklerini varsaymaktadır. Bu ayrım Powell, Lovallo ve Fox [6]'un sırasıyla kaynak avantajları ve piyasa gücü sınıflandırmasına denk gelmekte olup, Bromiley ve Rau [7] davranışsal yaklaşımı üçüncü yaklaşım olarak ifade etmektedir.

Stratejik yönetime davranışsal yaklaşımlar son yıllarda ortaya çıkmakla beraber, ekonomik (rasyonel) yaklaşımlara meydan okuyan psikoloji temelli çalışmaların izi 1950'li yıllara kadar götürülebilmektedir. O dönem, başlarını Herbert Simon, James March ve Richard Cyert'in çektiği ve sonradan Carnegie Okulu şeklinde adlandırılacak çalışmalar zinciri, işletme politikası ve stratejisi alanının ilk dönem gelişimine katkıda bulunmuştur $[8,9]$.

Bahsedilen psikoloji temelli çalışmalar Augier, Fang ve Rindova [10]'ya göre üç kategoriye ayrilmaktadır. İlk kategori Hambrick ve Mason [11] tarafından önerilen üst kademe (upper echelons) yaklaşımıdır. Yayınlandığı günden bu yana stratejik yönetim araştırmalarını domine eden bu yaklaşıma göre; genel müdürlerin demografik ve insani özellikleri ile üst yönetim takımlarının yapısı, oluşumu ve dinamiği stratejik seçimler ile firma performansını açıklamaktadır. Üst kademe teorisinde stratejik karar vericilerin bilgi işleme özellikleri üzerinde bireysel ve grup karakteristiklerinin etkisi olduğuna vurgu yapılmaktadır. İkinci kategori Gavetti, Levinthal ve Ocasio [8]'nun belirttiği üzere Neo-Carnegie geleneği olarak ifade edilmektedir. Bu gelenekte Cyert ve March [12]'1n bireylerin önceliklerini güncellemediklerini ve optimal şekilde öğrenmediklerini iddia eden davranısssal firma teorisi; Nelson ve Winter [13]'ın bireylerin rutinlere ve statükoya bağl1 kalarak bütün seçenekleri dikkate almadıklarını gösteren evrimsel ekonomi teorisi; Levinthal [14]'ın öğrenmenin birbirine bağl1 bağlamlarda nasıl karmaşık olduğunu gösteren NK yaklaşımı ile March [15]' in stratejik yönetimin uyumsal zeka ve hatta aptallık tarafından kazanımlar elde edeceğini gösteren çalışması etkili olmuştur. Son kategori ise örgütlerdeki yorumlama süreçlerini stratejik yönetim konularıyla ilişkilendiren, özellikle de tehditler ile fırsatların çerçevelendiklerini [16], rekabet gruplarının zihinsel süreçlerle oluşturulduğunu [17] ve yöneticilerin stratejik kararları zihin setlerinde ve bilişsel şemalarında depolanan baskın mantıkla aldıklarını [18] ifade eden bilişsel perspektiftir. Stratejistlerin, bilişsel süreçlerinin bir işlevi olarak firmanın çevresini yorumladıklarını öne süren bu perspektif, çevresel karmaşıklığın kısmi temsillere ve potansiyel olarak sınırlı rasyonel kararlara yol açtığını iddia etmektedir.

Son dönemde ise stratejik yönetimin alt alanı olarak davranışsal strateji tanımları yapılmıştır. Öncü tanıma göre davranışsal strateji; bilişsel ve sosyal psikolojiyi stratejik yönetimin teori ve pratiğiyle birleştirmektedir. Böylelikle davranışsal strateji insani biliş, duygular ve sosyal davranışlarla ilgili gerçekçi varsayımları örgütlerin stratejik yönetimine getirmeyi ve strateji teorisini, ampirik araştırmaları ve gerçek dünya uygulamalarını zenginleştirmeyi amaçlamaktadır [6].

Stratejik yönetime diğer bir davranışsal yaklaşım Gavetti [19]'den gelmiştir. Gavetti [19]'ye göre davranışsal terimi, belirli bir olgunun psikolojik temelleri olmakla birlikte, geniş anlamda zihinsel süreçlerle ilgilidir. Bu zihinsel süreçleri yönetmek mümkün olduğu için yaygın düşünüş biçimlerinin dışarısında bir yerde yatan bilişsel olarak uzak firsatları keşfetmek ve takip etmek mümkündür. Piyasalar etkin olduğunda stratejik fırsatlar oluşmayacaktır. Bu yüzden piyasaların etkin işlemesini engelleyen davranışsal faktörler, aynı zamanda firsatların ortaya çıkmasını sağlayan nedenlerdir. Stratejinin nihai amacı üstün performans olduğu için üstün performansı sınırlayan davranışsal başarısızlıklar, stratejik liderlerin zihinsel süreçleri yönetme yeteneğiyle baş edilebilir. Bu yüzden de üstün performans; liderlerin bu yeteneğinde yatmakta olup, zihinsel süreçleri yönetmek stratejik liderlerin esas rolüdür. İfade edilen bu yaklaşım, stratejik yönetim üzerine getirilmiş davranışsal yaklaşımların stratejik faillik (strategic agency) kavramına yüklediği anlamı genişletmektedir.

Winter [20] serendiplik ve örgütsel faktörleri dışarıda tutmasından ötürü Gavetti [19]'nin davranışsal strateji teorisini eleştirmiştir. Ekonomik biliş; teknoloji, yetenekler ve piyasa durumları gibi bağlamsal faktörlere dayanmaktadır. $\mathrm{Bu}$ nedenle de davranışsal strateji alanı zihinsel süreçlerin yanında bağlamsal gerçekliklilere de yer açtığı takdirde, stratejik yönetimin diğer açıklamalarının başarılı bir tamamlayıc1sı olabilecektir. 
Öte yandan Levinthal [21] stratejik yönetimin ekonomik (rasyonel) ve davranışsal şeklinde ikili bir ayrıma gitmesini yanlış bulmaktadır. Levinthal [21]'a göre rasyonel seçim hesaplarının yapımından önce problem çerçeveleme ve temsil eylemi gerekmektedir. Dolayısıyla bir davranışın rasyonel seçim karakterizasyonu ile davranışsal açıklamalar arasındaki etkileşim önemli ölçüde iç içedir. Yöneticilerin yaratılıştan gelen insani eksiklikleri göz önünde tutularak, asıl soru stratejik bağlamlarda zeki ve etkili eylemlerin nasıl yapılacağıdır. Rasyonelliğin bir sonuç değil süreç olarak görülmesiyle; uyumsal ögrenme, seçilim mekanizmaları ve taklit süreçleri gibi davranışsal mekanizmalar, ihtiyatlı akıl yürütme ve analiz mekanizmalarına dâhil edilmelidir. March [22]'ın da belirttiği üzere örgütler yapıp ettiklerini; niyetli ancak sinırlı rasyonellik, hayatta kalma ile kopyalama, deneme yanılma yoluyla ögrenme ve taklit ve yayılma ağları nedeniyle yaparlar.

Görüldüğ̈̈ üzere davranışsal strateji hakkında birçok tanım ve yaklaşım bulunmaktadır. March [22] belirsiz görünen bu duruma minimalist bir yaklaşımla strateji, stratejik yönetim ve davranışsal strateji tanımları yapmıştır. O’na göre strateji, nispeten uzak bir gelecekteki sonuçlar ile önemli ölçüde rakiplerin eylemlerine bağlı olan sonuçları vurgulayan bir gelecek eylemi planıdır. Stratejik yönetim, olumlu sonuçlar doğuran bir strateji yaklaşımı keşfetmeyi araştırmaktadır. Davranışsal strateji ise örgütlerdeki stratejilerin benimsenme süreçleri ile davranışsal karakteristiklerin strateji yapımındaki etkilerini anlamayı araştırmaktadır. Bu haliyle davranışsal strateji alanı işletme eğitimi için önemlidir ancak entelektüel katkısı tam olarak açık değildir. Cevaplardan çok sorulara dayanmaktadır. Davranışsal stratejiye araştırma-kullanma (exploration-exploitation) lensinden bakılarak, bu alanın yeni konuları araştırması gerekmekte ve bu araştırmanın da karar verme çalışmalarıyla sınırı kalması gerekmektedir.

Stratejik yönetime yapılan davranışsal yaklaşımların ortak özelliği insani bilgi işlemeyle ilgili ortaya konan teorileri kullanmasıdır. Karar vericilerin sınırlı rasyonellik gösterdiklerini, bilgi işleme kapasitelerinin kısıtlı olduğunu ve optimal kararlar yerine yeteri kadar iyi kararlar aldıklarını ifade etmektedir. İnsani bilgi işlemeyle ilişkili olarak sınırlı rasyonellik, zaman ve kaynak kısıtları, çoklu hedefler, algılar ve yanlılıklar, motivasyon, ögrenme, gruplar ve takımlar ve son olarak bilinmeyen optimum; davranışsal stratejinin önemli varsayımlarıdır [7]. Dolayısıyla davranışsal strateji alanı ve ifade edilen tanımlar, doğası gereği betimleyici özelliktedir. Stratejik yönetimin gerçekte nasıl olduğunu açıklamaya çalışmaktadır. Bromiley ve Rau [7] davranışsal yaklaşımların; örgütlerin veya bireylerin stratejik bağlamlarda nasıl davranması gerektiklerini normatif bir şekilde ifade etme zamanının geldiğini söylemektedirler. Yazarlar örnek olarak stratejikleştirme, yönetim teknolojisi, firma sınırları, yönetim kurulunun rolleri, yönetsel motivasyon, insani ilişkiler, performans ve yetinmenin ölçümü ile değişim konularında yönergeler çıkarmışlardır.

Davranışsal stratejiyi bir alandan ziyade psikolojik görüşleri içerisinde barındıran bir stratejik karar verme tarzı olarak görenler de bulunmaktadır. Lovallo ve Sibony [23] analiz ettikleri 1048 kararda birçok bilişsel yanlılığın olduğunu görmüşlerdir. Bu bilişsel yanlılıkları psikoloji ve davranışsal ekonomi bulgularından hareketle eyleme dönük, çıkar, örüntü tanıma, durağanlık ve sosyal yanlılıklar şeklinde beş sınıfta toplamışlardır. Stratejik kararlardaki bu yanlılıkları ortadan kaldırmak için ise çeşitli önerilerde bulunmuşlardır. Örneğin aşırı iyimserlik, aşırı güven ve rakip ihmali gibi eyleme dönük yanlılıklara karşı koymak için stratejik karar verme sürecinde belirsizliğin tanınmasına yönelik teşviklerin faydalı olabileceğini söylemişlerdir. ${ }^{1}$ Yöneticilerin davranışsal bir stratejiyi nasıl oluşturacakları Lovallo ve Sibony [23]'ye göre dört adımda gerçekleşecektir: hangi kararların bu yönde bir çabayı gerektirdiğine karar vermek, kritik kararları etkilemesi daha muhtemel olan yanlılıkları belirlemek, en yüksek alaka düzeyine sahip yanlılıkları ortadan kaldırmak için uygulama ve araçları seçmek, bu uygulamaları şirket süreçlerinin içerisine yerleştirmek. Görüldüğü üzere bu adımlar üst yönetimin büyük bir çaba ve bağlılı̆̆ını gerektirse de, ortaya çıkacak fayda atılacak bu adımları firmaların yapabileceği stratejik yatırımların en önemlilerinden biri haline getirmektedir.

\footnotetext{
${ }^{1}$ Diğer bilişsel yanlılıklar hakkında detaylı açıklamalar ve bu yanlılıkların nasıl ortadan kaldırılabileceği ile faydalı öneriler için bkz. [23].
} 
Greve [24] ise firmaların eylemlerinde görülen davranışsal stratejileri rasyonellik düzeyine göre açıklamıştır. Davranışsal stratejiyi bazı uyumsal sonuçlarıyla birlikte sistematik bir davranışsal şablon şeklinde ifade ederek en az dört çeşit davranışsal strateji olduğunu göstermiş̧ir: momentum, geribesleme, çıkarımsal ve beklentisel. Bu stratejiler Cyert ve March [12]'da açılanan standart işlem prosedürleri ile Nelson ve Winter [13]'da ayrıntılandırılan rutinlerden farklıdır çünkü davranışsal stratejiler örgütsel eylemleri modifiye etme mekanizmalarıdır. Oysa standart işlem prosedürleri ile rutinler örgütsel eylemlerin ta kendisidir. Firmalarda görülen momentum stratejileri sonuçlar incelenmeksizin tekrar edilen davranışlardır. Yatırım kararlarında görülen bağl1lık süreçleri ile ortak yatırımlarda bulunan firmalar arasındaki güven süreçleri momentum stratejilere güzel örneklerdir. Verilen kararların sonuçları zamansal anlamda uzak olduğunda, karmaşık atfetmeler barındırdığında veya muğlak değerlendirme kriterlerine sahip olduğunda momentum stratejiler için şartlar oluşmuş demektir. Bu yönüyle de basit olup, düşük rasyonellik düzeyi sergilerler. Geribesleme stratejileri performansla ilgili arzu düzeyleri ile başarılar veya başarısızlıkların firmanın eylemlerine yüklenmesine yönelik karar verme teorisine dayanmaktadır. Bu stratejiler, yapılan eylemler başarılı sonuçlarla ilişkilendirildiğinde mevcut eylemleri devam ettirirler; başarısız sonuçlarla ilişkilendirildiğinde ise alternatif eylemler üretmek için kullanılırlar. Geribesleme stratejilerinin birçok kaynağı bulunmaktadır. Örgütsel anlamda, firmalar hedef çatışması ve belirsizliği arzu düzeylerini ayarlayarak ele alırlar. Böylelikle de arzu düzeyinin altında olan hedefe dayanarak, hedef değişkenlerine gösterilen dikkat düzeyi artar veya azalır. Bireysel anlamda, ödül araştırma davranış şablonlarından davranışları çeşitleme ve inançları güncelleme yoluyla izlenim oluşturma süreçlerine kadar birçok açıklama vardır. Risk alma durumunu baz alan diğer açıklama ise, bireylerin ve örgütlerin davranışlarında görülen arzu düzeyinin altında bir performans gösteriminden dolayı risk eğiliminde artışın olacağını söylemektedir. Geribesleme stratejilerinde, momentum stratejilerin aksine, sonuca dair kolayca ulaşılabilir bilgiler gereklidir çünkü bu bilgiler sayesinde önceki eylemlerle bir ilişki kurulabilir. Ulaşılabilir bilgi çıkarımsal stratejiler için de önemlidir ancak bu davranışsal stratejilerde bilgi başarı veya başarısızlığın doğrudan bir sinyali değildir. Bunun yerine diğer firmalarla ilgili olayları firmanın eylemleriyle ilişkili olarak yorumlama vardır. Bu stratejilerin en fazla görüldüğü alan yönetim uygulamaları ile örgüt yapılarının meşrulaşma sürecidir. $\mathrm{Bu}$ nedenle başarılı firmaların uygulamalarının taklit edilerek benimsenmesi en basit çıkarımsal strateji biçimidir. Rasyonellik ölçeğinin en üst noktasında yer alan beklentisel stratejiler, başka firmaların eylemlerini tahmin etme ile bu tahmine optimal şekilde karşlık gelen eylemleri seçmeyi kapsamaktadır. $\mathrm{Bu}$ stratejiler -oyun teorisinde olduğu gibi- farklı alternatiflerin getirisine ve birbirlerinin sonuçlarını karşl1ıklı etkileyen aktörlerin eylemlerine dayanan rasyonel seçimi içermektedir. Rasyonel seçimle açık bir şekilde ilişkili olsa da beklentisel stratejiler sınırlı rasyonellik ve öğrenme ile de uyumludur. Birden fazla piyasada faaliyet gösteren rakip firmalar arasındaki karşılıklı hoşgörü durumunda ve işbirliği yapan firmalar arasında beklentisel stratejiler görülebilmektedir. Greve [24]'in davranışsal stratejiler incelemesinin temelinde yatan olgu; firma davranışlarının kararlardan doğduğu ve bu davranış setinin sistematize edilmesiyle onları üreten karar verme süreçlerinin gözlemlenebilir olacağıdır.

Davranışsal strateji; stratejik karar verme biçimi veya kararlardan doğup eylemleri modifiye eden bir mekanizmadan öte bir alan olarak ele alındığında Powell, Lovallo ve Fox [6]'un da belirttiği üzere yapılan araştırmaların üç okul içinde kümelendiği görülmektedir: İndirgemeci (Reductionist), Çoğulcu (Pluralist) ve Bağlamsalcı (Contextualist). Bu okulların tamamı stratejik yönetimin psikolojik temellerini açıklayan çalı̧̧malar yapsa da odak noktaları farklıdır. İndirgemeci okul; bireysel yargı ve kararları deneysel ve nicel yöntemlerle çalışmakta ve davranışsal ekonomi ile davranışsal karar vermede temellenmektedir. Çoğulcu okul; bireysel bilişi, sosyal psikolojiyi ve öğrenme ve işletme içi pazarlık gibi örgütsel olguları hesaba katarak firmanın karar çevresini birçok istatistiksel yöntemle çalışmaktadır. Bağlamsalcı okul ise örgütsel ve stratejik bağlamlardaki bireylerin dünya görüşlerine ve algısal çerçevelerine vurgu yaparak nitel veya yorumlayıcı yöntemleri kullanmaktadır [25].

Davranışsal strateji alanını belirlemeye yönelik girişimler Powell, Fox ve Lovallo [6]'dan sonra çeşitli şekillerde yapılmaya çalışılmıştır. Bunlardan en tanımlayıcı olarak görülebilecek Hambrick ve Crossland [26]'in küçük, ortaboy ve büyük şeklinde ifade edilen üç çadır versiyonunda, alana sosyolojik ve politik faktörlerin de dahil edilmesi önerilmiştir. Küçük çadır davranışsal ekonominin 
stratejik yönetime doğrudan aktarılmasını içermektedir ve davranışsal kamu yönetimi alanı için de önerilen bir yaklaşımdır [27]. Rasyonellikten sapmalar şeklinde adlandırılan karar vermedeki bilişsel yanlı1ıklar ile kestirme yollara odaklanmaktadır. Ancak örgütsel koşullarda kısıtlayıcı bir yapısı olduğu için önemli ancak yetersiz görülmektedir. Ortaboy çadır; stratejistlerin psikolojilerini bilişsel, sosyal, kişilik ve kültürel psikoloji gibi alanlardan faydalanarak anlama girişimidir. Yazarlara göre bu çadır davranışsal stratejinin kapsamını belirlemede ne çok dardır ne de çok geniştir; doğru dengedir. Firma heterojenliğine sebebiyet veren stratejistler arasındaki yatkınlık farklılıkları, karar vermeyi etkileyen şema, dikkat ve öğrenme gibi bilişsel öncüller ve üst yönetim takımlarının oluşum ve süreçleri davranışsal stratejinin ortaboy çadırının en önemli araştırma alanlarıdır. Büyük çadır ise sosyopolitik süreçlerin psikolojik süreçlerden ayrılamayacağını iddia ederek; örgüt kültürünü, sosyal onay varlıklarını (örneğin statü, prestij, itibar, şöhret vb.) ve politik süreçleri (çekişen hedefler, kimlik güdümlü koalisyonlar, çıkarlar gibi) stratejik karar verme süreçlerine dahil etmektedir.

Bir realite olarak kendini gösteren davranışsal stratejinin büyük çadırı oldukça önemlidir çünkü firmalar rekabet avantajlarına sahip olmasalar bile siradan faaliyetlerini titizlik ve gayretle uygulayarak rekabette öne geçebilirler. Rasyonel görüşün belirttiğinin aksine gerçek koşullardaki insanlar daha etkileyicidir. Onlar tutku, yardımseverlik, içgörü ve azim özelliklerine sahiptirler. Ahlaki ve estetik idealleri vardır ve diğerkâmlık, güven, karşılıklılık, merhamet, adalet, sadakat ve sevgi gösterirler [28].

Davranışsal stratejinin kapsamını genişletme girişimlerinden biri de Augier ve Dew [29]'den gelmiştir. Carnegie Okulu'nun üyelerinden biri olarak anılan Herbert Simon'ın çalışmalarına dayanarak bir yol haritası oluşturan yazarlar; disiplinlerarasılık, deney güdümlülük, metodolojik çoğulculuk ve iki yönlü öğrenme açısından önerilerde bulunmuşlardır.

Benzer şekilde Westphal [30] sadece bilişsel ve sosyal psikolojiyi stratejik yönetime dahil eden öncü davranışsal strateji tanımının alanda benimsenmediğini belirtmiştir. Öncü görüş alanda içgrup/dışgrup dinamiği oluşturmuş ve kategori liderlerinin çizdiği davranışsal strateji alanı ile kategori üyelerinin yürüttüğü çalışmalar arasında bir ayrışma ortaya çıkarmıştır. Ayrıca davranışsal stratejinin diğer alanlardaki ve akademi dışındaki etkisini de azaltmıştır. Bu nedenle Westphal [30], kültürel ve yapısal sosyolojiden de faydalanarak tanımlayıcı davranışsal mekanizmaları içeren daha disiplinlerarası bir yaklaşım önermektedir. Bu davranışsal mekanizmalar farklı analiz düzeylerindeki sosyal ve psikolojik süreçlerin strateji ve performansa etkide bulunmak adına nasıl birbirini etkileyeceğini ve ilişkilendireceğini açıklamaktadır.

Görüldüğ̈̈ üzere davranışsal strateji alanı son yıllarda artan bir ilgiye sahiptir. Sonraki bölümlerde Powell, Lovallo ve Fox [6]'da ifade edilen sinıflandırmayla uyumlu şekilde indirgemeci, çoğulcu ve bağlamsalcı orman ürünleri sanayi çalışmaları gösterilecektir. Seçilen çalışmalar Powell, Lovallo ve Fox [6]'da alana önemli katkı sağlayan kişiler baz alınarak Google Akademik veritabanı yardımıyla belirlenmiştir. Orman ürünleri sanayi göz önünde tutularak yapılan bu belirleme işlemi sonucunda indirgemeci okul kapsamında iki, çoğulcu okul kapsamında iki ve bağlamsalcı okul kapsamında dört çalışma incelenmiştir.

\section{III. İNDIRGEMECI OKUL}

İndirgemecilik, olgular arasındaki ilişkilerin daha basit veya daha temel olgular açısından açıklanabileceğini söyleyen teoridir [31]. Felsefi anlamda en fazla ama en yanlış kullanılan terim olan indirgemecilik üç kısma ayrılabilir [32]. Ontolojik indirgemeciliğe göre; gerçekliğin tamamının çok az sayıdaki oluşumdan meydana geldiğini iddia etmektedir. Metodolojik indirgemecilik, "en iyi bilimsel strateji açıklamaları en küçük parçalara indirmeye girişmektir" görüşünü savunur. Teori indirgemeciliği ise yeni bir teorinin eski teorinin yerini alamayacağını veya eski teoriyi kendine dahil edemeyeceğini; sadece daha temel terimlere indirgeyeceğini öne sürer. Ackoff [33]'a göre indirgemecilik bütün nesne ve olayların bölünemez temel öğelerden oluştuğunu iddia eden bir doktrin 
olup, öğeleri analiz ederek nesne ve olaylarla ilgili kavrayışlar elde edebiliriz. Bir diğer tanımda indirgemecilik daha karmaşık, çetrefilli olgu ve konuları bileşenlerine, onları oluşturan temel bir özelliğe indirgeyerek açıklamaya çalışmaktır [34]. Tetlock [35]'a göre indirgemeciler çoğu az ile açıklamaya çalışırlar, cimriliğe değer verirler ve yüzeysel olarak farklı olguların temelde yatan yaygın bir nedenin ürünü olduğunu öne sürerler.

Davranışsal strateji alanının indirgemeci okulu; pozitivist, gerçekçi ve objektivist bilim felsefelerine dayanmaktadır. Matematiksel modelleme, benzetim, laboratuar deneyleri gibi yöntemleri kullanarak nicel hipotez testleri yapmaktadır. İndirgemeci yaklaşım; stratejik karar verme, bilişsel yanlılıklar (artan bağlılık, kazananın laneti ve rekabetçi kör noktalar gibi), risk algısı ve zamanlararası seçim konularına önemli katkılar yapmıştır. Bu okulun temel psikolojik kavramları sınırlı rasyonellik, beklenti teorisi, kestirme yollar ile yanlılıklar ve dinamik tutarsızlıktır. Firmalarla ilgili varsayımları ise kararların üst yöneticiler ve üst yönetim takımlarınca alındığı ve kararların bilişsel yanlılıklara tabi olduğudur [6].

İndirgemeci okul stratejik kararlarla ilgili bilişsel yanlılıkları ve kestirme yolları ortaya koyarak stratejik yönetim için önemli kazanımlar sunmuştur. Örneğin işletme satın almalarında aşırı risk almanın CEO'ların aşırı güveni ve kibriyle bağlantılı olduğu [36], piyasalarda girişimcilik faaliyetlerinin gereğinden fazla olmasının miyopik kendine odaklanma ve rekabet ihmalinden doğduğu [37], batık maliyetlere devam etme ile statükoya çıpalamanın kaynak tahsislerini saptırabileceği [38] ve yöneticilerin tercih edilmiş stratejileri yanlış benzetmeler oluşturarak veya sınırlı veriyle ilgili yanlış çıkarımlar yaparak doğruladığı [39] indirgemeci zihniyetle çalışan araştırmacıların bulgularıdır.

Orman ürünleri sanayinde indirgemeci bakış açısıyla yapılmış davranışsal strateji çalışmalarından biri Filbeck, Gorman ve Preece [40]'ye aittir. Endüstri içi sermaye yapısı kararlarının davranışsal yönlerini inceledikleri çalışmalarında Filbeck, Gorman ve Preece [40], aralarında orman ürünleri, uzay, kimya, kozmetik, yayıncılık, ilaç ve cam sanayilerinden 120 firmanın bulunduğu bir veri setiyle çalışmışlardır. Bu örneklemde orman ürünleri sanayiden 17 firma bulunmaktadır. Yazarlar temel olarak iki hipotezi test etmek istemişlerdir. Birincisi Patel, Zeckhauser ve Hendricks [41] tarafindan önermesi yapılan sürü göçü hipotezi; ikincisi ise firmaların finansal kararlar alırlarken sanayi liderlerini takip edebilecekleri hipotezidir. Sürü göçü hipotezi, insanların bugün alacakları kararların kârlı olabilmesi için daha önce başkaları tarafindan alınmış olması gerektiğini söylemektedir. Yatırım fonu piyasalarında insanların satın alma davranışlarını açıkladıkları bu hipotezde, piyasa şartları değiştiğinde bireysel karar vericiler de tercihlerini değiştirmektedirler.

Bu çalışmada Quattrone ve Tversky [42]'nin kendini aldatma (self-deception) kavramı da davranışsal açıklama olarak kullanılmıştır. Kendini aldatma bireylerin esasında hiçbir sonucu olmayan eylemlerde bulunduklarını çünkü kendilerini o eylemin önemli olduğuna inandırdıklarını ifade etmektedir. Filbeck, Gorman ve Preece [40]'ye göre sermaye yapıs1 politikaları, hissedarlar politikası, şirket birleşme dalgaları ve yeni özkaynak sorunları kendini aldatma davranışıyla açıklanabilecektir.

Sanayi analistleri ve yöneticilere sorularak yukarıda belirtilen 7 sanayi dalındaki liderler belirlenmiştir. $\mathrm{Bu}$ belirleme işleminde yönetim kalitesi ve şirketin ürün ve hizmetlerinin kalitesi gibi kriterler göz önünde tutulmuştur. Her dönem bir sanayi liderinin açık bir biçimde gözükmemesi sonucunda, 1981 1990 arasındaki sanayi liderleri tespit edilmiştir. Ardından 120 firmadan toplam borç, toplam kaynak, özkaynak bilanço değeri, özkaynak piyasa değeri ve uzun dönem borç ile ilgili veri toplanmıştır. Yapılan regresyon analizleri sonucunda Patel, Zeckhauser ve Hendricks [41]'in firmaların sürü davranışından bulunduklarına dair hipotezi orman ürünleri sanayinde desteklenmemiştir. Sermaye yapısı kararlarında sanayi liderini takip etme hipotezi ise zayıf olarak desteklenmiştir. Orman ürünleri sanayi firmalarının örgütsel performansın nedensel sonuçlarıyla tanısal yönlerini ayırt etmede yanılgıya düşmedikleri görülmektedir. Dolayısıyla orman ürünleri sanayi firmaları sermaye yapısı kararları alırlarken vekâlet maliyetleri, iflas maliyetleri, yanlış yatırım gibi birçok faktörü göz önünde tutmaktadırlar. 
İndirgemeci paradigmayla yapılan bir diğer çalışmada Michael ve Ray [43] davranışsal karar verme araştırmalarının sonuçlarından biri olan bilişsel yanlılıkları [44] orman ürünleri sanayi kapsamında ele almıştır. Yazarlara göre yönetsel karar verme orman ürünleri işletmelerinin davranışlarını ve ortaya çıkabilen istenmeyen sonuçları doğrudan ya da dolaylı etkilemektedir. Yöneticilerden topladıkları bilgilerden ve yıllar içinde sektörden edindikleri deneyimlerinden faydalanarak hazırladıkları çalışmalarında, sanayi liderlerinin verdikleri kararları yeniden dikkate almalarını teşvik etmek amaçlanmıştır.

Michael ve Ray [43] yönetsel kararların devasa olumsuz sonuçlar doğurduğunu, Amerikan OSB sektöründen örneklendirmektedir. Louisiana-Pacific adlı şirketin iki yöneticisi, baca dumanını saklamak için gece üretimini arttırarak ve böylece eyaletin temiz hava yasasını ihlal ederek emisyon denetimini kurcalamakla itham edildiler. Bunun yanı sıra şirkete gelen muhasebe denetçilerini de aldatma girişiminde bulundular. Durum anlaşılınca yöneticiler dokuz ay hapis cezasına çaptırıldılar. Şirket ise 37 milyon dolar para cezası ödemek zorunda kaldı. Kötü kararlara örnek olarak OSB pazarına ilk başta girmeyen, sonradan ise yarı optimal rekabetçi hamleler yapan orman ürünleri firmaları da gösterilmektedir. Böylelikle bu firmalar OSB pazarının yüksek kar marjını elde edememişler ve kontrplak sektörünün düşük kar marjına razı olmuşlardır.

Yazarlar bu tip örnekleri bulunan yanlış yönetsel kararların nedenleri olarak birtakım bilişsel yanlı1ıkları göstermişlerdir. Bunlardan en yaygın olarak ifade ettikleri aşırı güven (overconfidence) yanlılığıdır. Başarısızlık olasılığının azımsandığı ve böylelikle kötü stratejik kararların doğduğu bu yanlılık, bireylerin kendilerini ortalamanın üzerinde görmeleri biçiminde de karşımıza çıkmaktadır. Laboratuar ortamında tasarladıkları bir deneyde yöneticilere müzakere, karar verme, araba kullanma, problem çözme gibi yetenekleri ve zeka, dürüstlük, fiziksel çekicilik gibi durumları soruldu. En iyi olma durumunda 100, en kötü olma durumunda ise 0 cevapları işaretlendi. Sonuçların ortalamasının 50 olması gerekiyorken, en düşük ortalamanın 58,3; en yüksek ortalamanın ise 84,4 olduğu görüldü. Örneğin dürüstlük 84,4 , zihinsel stabilite 74,9 , araba kullanma yeteneği 73,8 , problem çözme yeteneği 70,4 olarak kaydedildi. Bu sonuçlar yöneticilerde aşırı güven yanlılığının olduğunu göstermektedir.

Gösterilen diğer bilişsel yanlılık kazananın lanetidir. Kazananın laneti (winner's curse) olgusunda kişiler isteyerek ve ısrarlı bir şekilde kayıp getiren satın almalar gerçekleştirmektedirler. Kişiler arasında asimetrik bilginin olması durumunda gerçekleşen kazananın laneti açık artırma vakalarında görülmektedir. Bir şeyi satın almak isteyen kişi satan kişinin razı olduğu fiyatın çok üzerinde bir fiyatla açık artırmanın kazananı olduğunda aslında zarar etmiş olacaktır. Burada satın almak isteyen kişi başkalarının olası kararlarını dikkate alarak mevcut olacak bilgiyi yetersiz bir şekilde göz önüne alma eğilimi göstermektedir [45].

Bazen yöneticiler bir eylem için karar verirler ancak istedikleri sonucun gelmediğini görürler. Rasyonel bakış açısıyla eylemin durdurulması gerekirken, yöneticiler verdikleri kararın arkasında durarak kaynak tahsisine devam ederler. Bu durum artan bağlılık (escalation of commitment) yanlılığ olarak ifade edilmektedir [46] ve orman ürünleri sanayi firmalarında da yaygın olarak görülmektedir.

Çalışan sayısı fazla olan orman ürünleri işletmelerinde görülen bir diğer yanlılık örgütsel siloların oluşumudur. $\mathrm{Bu}$ durumda kritik bilgiler tepedeki karar vericilere doğru akmaz. Bunun nedeni bir departmanın şirket içinde etkili bilgi paylaşımı yapmamasıdır. Bilgi çağının getirdiği internet, intranet gibi uygulamaların bu durumu bitireceği düşünülse de bu gerçekleşmemiştir çünkü kritik bilgiler hala kişilerce tutulabilmektedir. Bu tür bilgilere erişimi olan yöneticiler içe odaklanmaktadırlar. Böylelikle de stratejik karar verme süreçleri optimallikten uzaklaşmaktadır.

\section{COĞULCU OKUL}

Çoğulcu yaklaşım yönetim ve örgüt çalışmaları ile stratejik yönetimde tartışılan bir konudur. Kimileri teorik ve yöntemsel anlamda birliği savunurken; kimileri de çokluğu desteklemektedir. Genel görüşe 
göre, araştırma problemlerine uygulanan teorik ve yöntemsel çoğulculuk hem yaygınlık hem de farklılıkça zenginleştirilmiş artımsal ve birikimsel kavrayışlar ortaya çıkarabilir [47]. Scherer [48]'in belirttiği üzere teorik çoğulculuk bereketli bir genişleme şeklinde görülmektedir ve içinde barındırdığ1 emsalsizliğin kendi başına bir bilimsel değeri olduğu için araştırmacıların her zaman daha fazla perspektif oluşturma güdüleri olmuştur. Çoğulcu yaklaşımı benimseyenler, alanın uzun vadede daha iyi büyümesini teori ve yöntemlerdeki çoğulculuğa bağlamaktadırlar. Neden olarak ise; 1) alandaki çoğu teorinin içinde yaşadığımız dünyanın sadece bir yönüne 1şık tutması sebebiyle oldukça karmaşık gerçeklikleri anlamak için farklı teorilerin gerekli olduğu ve 2) birçok teorinin rekabeti teşvik ettiği ve böylelikle de bilimsel gelişme ihtimalini arttırdığı gösterilmektedir [49].

Davranışsal stratejinin çoğulcu okulu; pozitivist, nominalist, pragmatist veya evrimsel bilim felsefelerini benimsemiştir. Birçok teorik gelenekten faydalandığı ve vaka çalışmaları, benzetim, büyük örnekli alan araştırması gibi birçok yöntemi kullandığı için çoğulcu olarak adlandırılmıştır. Bu okulun temel psikolojik kavramları referans grupları, sosyal biliş, sosyal kimlik ve benlik sınıflandırmasıdır. Davranışsal firma teorisi, üst kademe teorisi, grup özdeşleşmesi, arzu düzeyleri, uyumsuz öğrenme ve örgütsel nevroz konularında önemli katkılar yapmıştır. Firmalarla ilgili varsayımları indirgemeci yaklaşımdan farklıdır. Bu varsayımlar; 1) firmaların çatışan hedeflere ve perspektiflere sahip altgruplardan oluştuğu ve 2) firmaların stratejik problemlerini çatışma çözülümü ve gruplararası pazarlıkla çözdüğüdür [6].

İndirgemeci okulun aksine firmanın genel karar çevresine odaklanan çoğulcu okul, stratejik yönetim alanında etkili çalışmalar ortaya koymuştur. Örneğin firmanın yeni bilginin değerini tanıma, bunu benimseme ve ticari amaçlarına uygulama yeteneğinin firmanın sahip olduğu bilgilerin bir fonksiyonu olduğu [50], üst yönetim takımlarının bilişsel ve demografik özelliklerinin stratejik sonuçlar üzerinde etkili olduğu [11], şirket birleşmelerinde düşük statülü şirket çalışanlarında iç grup yanlılı̆̆ının oluştuğu [51] ve gruplardaki bireylerin birbirlerinin zihinsel modellerini anlamalarının öğrenme ve performansı arttırdığ1 [52] çoğulcu yaklaşımla ele alınan araştırmaların bulgularındandır.

Orman ürünleri sanayinde çoğulcu perspektifle yapılmış çalışmalardan biri Wiersema ve Bantel [53]'e aittir. Kurumsal stratejik değişim ile üst yönetim takımının demografik özellikleri arasındaki ilişkinin incelendiği bu çalışmada, üst kademe teorisinden faydalanılmıştır. Bu teoriye göre üst yönetim takımlarının bilişsel ve demografik özellikleri stratejik sonuçları ve performansı etkilemektedir. Yöneticilerin bilişsel temelinin karar vermenin temelinde yatan algısal süreci etkilediği üç aşamada gerçekleşmektedir. İlk olarak bilişsel temel yöneticinin vizyon alanını diğer ifadeyle algısının yönleneceği çevresel alanları sınırlandırmaktadır. İkinci aşamada yönetici vizyon alanındaki uyarıcılara dikkatini yönelttiği için seçici algı olayı gerçekleşmektedir. Son olarak ise işlenen bilgi bilişsel temel lensiyle filtrelenmektedir [11].

Bir firmanın üst yönetim takımı, firmanın yönünü belirlemekten sorumlu bireylerden oluşan baskın koalisyon olup [12], çevresel firsat ve problemleri tanımlar, ilgili bilgiyi yorumlar, örgütsel yetenekler ile kısıtları düşünür ve stratejik değişim formüle edip, uygular [54]. Wiersema ve Bantel [53] bu bilgileri göz önünde tutarak, orman ürünleri, otomotiv, tekstil, petrokimya gibi birçok sanayi dalından firmayı örnekleme seçip, bu firmaların kurumsal çeşitlendirme stratejileri üzerinde üst yönetim takımlarının demografik özelliklerinin ne kadar etkili olduğunu araştırmışlardır.

Hazırladıkları modelde kurumsal çeşitlendirme stratejisi değişimi için dört eğilimi ortaya koymuşlardır. Değişime duyarlılık, risk alma istekliliğgi, bilgi kaynakları ile perspektiflerinin çeşitliliği ve yaratıc1-yenilikçi karar verme. Bu eğilimlerden ilk ikisi düşük yaş, kısa örgütsel deneyim, kısa üst yönetim takımı deneyimi, yüksek eğitim düzeyi ve teknik uzmanlaşma demografik özellikleri tarafından öne sürülürken; yaş, örgütsel deneyim, üst yönetim takımı deneyimi ve eğitim uzmanlaşması demografi heterojenliği son iki eğilimi telkin etmektedir.

Firmalar çeşitlendirme stratejisini yeni iş faaliyetleri ekleyerek, mevcut faaliyetlerini sonlandırarak veya yaptıkları işleri genişletme yoluyla büyümeye giderek değiştirmeyi seçebilirler. Orman ürünleri firmalarının da dahil edildiği firma setinin kurumsal çeşitlendirme stratejilerini ölçmek için Jacquemin 
ve Berry [55] ve Palepu [56] tarafindan geliştirilen entropi ölçümü kullanılmıştır. Bu ölçümde hem firmaların faaliyetleri üzerinden çeşitliliğin boyutu hem de çeşitlendirmenin ilişkili ve ilişkisiz olarak ayrılması hesaplanmaktadır. Sonuç olarak kurumsal stratejilerinde değişime giden orman ürünleri firmalarında; düşük yaş, kısa örgütsel deneyim, yüksek takım deneyimi, yüksek eğitim düzeyi, yüksek eğitsel uzmanlaşma heterojenliği ve yüksek fen ve mühendislik bilimleri eğitimi şeklinde karakterize edilen üst yönetim takımı demografisi bulunmaktadır. Dolayısıyla demografik özelliklere yansıyan üst düzey yöneticilerin bilişsel özelliklerinin kurumsal stratejiyi değiştirme eğilimiyle bağlantılı olduğu söylenebilir.

Çoğulcu yaklaşımla ele alınan Iaquinto ve Fredrickson [57]'da ise orman ürünleri sanayindeki üst yönetim takımlarına, stratejik kararların kapsamlılığı ve takım uzlaşması yönünden bakılmıştır. Üst yönetim takımının hedeflerde uzlaşma sağlamasının örgütsel başarı için kritik olduğu, önemli yönetim düşünürü Drucker [58] tarafından öne sürülmüştür. Takım üyelerinde amaçlanan uzlaşma stratejik karar verme sürecine dair ortak bir anlayışı yansıttığı, dolayısıyla da belirsizliği azalttığı ve kararların özüne odaklanmalarını sağladığı için önemli görülmektedir.

Yazarlara göre üst yönetim takımı uzlaşmasının önemi belirsizlik azaltma teorisinden anlaşılabilmektedir. Bu teoriye göre bireyler eğitilip, öğretildikçe; çalıştıkları örgütleri, işleri, beklenen davranışları ve mevcut normlarla ilgili bilgi kazanırlar. Bu bilgiler bireylerin belirsizliklerini azaltmalarına ve başkalarının davranışlarıyla ilgili tahminlerde bulunmalarına olanak sağlar. Bu durum karar verme davranışlarına yansır. Dahası, örgüt üyelerinin davranışlarını garantiye alacak ortak bir anlayışa motive olduklarını iddia eder [59, 60,61]. Dolayısıyla örgütsel rollere ve süreçlere ilişkin üyeler arasında uzlaşma düzeyi yükseldikçe; davranışların tahmin edilebilirliği artar, karşılaşacakları belirsizlik azalır.

Stratejik kararların kapsamlılığına ilişkin üst yönetim takımı uzlaşması firmanın faaliyette bulunduğu sanayinin durağanlı̆̆ 1 , geçmiş performanslar, örgütün büyüklüğü, takımın büyüklüğü ve üyelerin üst yönetim takımı deneyimi gibi bir dizi faktörden etkilenmektedir. Kapsamlılık örgütün stratejik kararlarını alma ve bütünleştirmede etraflı veya dahil edici olma derecesi olarak ifade edilmektedir [62]. Sonuçlara göre orman ürünleri firmalarındaki üst yönetim takımı uzlaşması örgütsel performansla pozitif ilişkilidir. Diğer bir sonuç örgütün büyüklüğünün uzlaşmayla negatif ilişkili olduğunu; geçmiş performansın ise herhangi bir ilişki barındırmadığını göstermiştir.

\section{BAĞLAMSALCI OKUL}

Bağlamsalcılık, herhangi bir soruyu cevaplarken bağlama başvurmanın önemini vurgulayan görüştür. Bu görüşe göre teorik terimler, yalnızca deneysel olarak test edilebilir teoremleri içeren tümdengelimli sistemlerdeki terimler şeklinde gözüktüğünde bir anlama sahip olur [34]. Bağlamsalcılar karmaşılı̆̆ın tadını çıkarırlar. Bugünün ana etkilerinin sıklıkla yarının etkileşimsel etkileri olacağını iddia ederler [35]. Bağlamın önemini çalışmalarında vurgulayan Weick [63]'e göre insanların deneyimleri kategorilenerek, peşin hüküm temelinde yakın dikkatte toplanır. Bu kategorilenmiş öğeler bağlamında ve peşin hükümlerin yol göstericiliğinde eylemde bulunan insanlar, bahsi geçen öğeleri gene bu peşin hükümler yönünde şekillendirirler. Dolayısıyla insanların eylemleri peşin hükümlerini onaylama eğilimindedir.

Bağlamsalcı okul fenomenolojik, inşacı, eleştirel ve postmodern bilim felsefelerine dayanmaktadır. Bağlamın önceliğini vurguladığı için böyle adlandırılmıştır. Bu yaklaşıma göre öznel inançlar, paylaşılan ideolojiler ve bilişsel çerçeveler tahmin ve varsayımlara dayanan kararlardan daha önemli olup; etnografi, söylem analizi, temellendirilmiş teori gibi yorumlayıcı yöntemler kullanılmakta ve nicel hipotez testleri reddedilmektedir. Anlam yaratma (sensemaking), algl, sahneleme (enactment) ve eylem üretimi gibi konular ilgilenilen süreçlerdir. Eylem rasyonelliği, bilişsel şema, bilişsel haritalar, bilişsel rekabet, baskın mantık, yanlış algılama ve bilinçli farkındalık konularına önemli katkılar yapmıştır. Bu okulun temel psikolojik kavramları bilişsel şema, dil, anlam, işaretler, ideoloji ve 
kültürdür. Firmalarla ilgili varsayımları ise firma ve çevrelerinin sosyal olarak inşa edildiği, firmaların ideolojik olduğu, kararlar ile eylemlerin birbirinden ayrıştı̆̆ 1 ve eylemlerin ortaya çıkan özellikte olduğudur [6].

Alınan kararlardan ziyade insanların veya firmaların gerçekte ne yaptıklarını kendi bağlamında çalışan bağlamsalcılar, stratejik yönetim alanına birçok fikir kazandırmıştır. Örneğin örgütsel eylemlerin, motivasyon ile bağlılığı maksimize eden irrasyonel karar verme prosedürlerine ihtiyaç duyduklarını [64], yöneticilerin geçmiş başarılarına güvenerek ciddi bir başarısızlık getirecek ince ayarlarla günü kurtardıklarını [65], yönetsel karar vericilerin kurumsal uygunluk uğruna rasyonel yenilikleri takip etmediklerini [66] ve örgütün imajı ile kimliğinin bireylerin stratejik konuları yorumlamalarına ve eylem motivasyonlarına yol gösterdiği; bu yorumlama ve motivasyonların ise zaman içinde örgütsel eylem şablonlarını şekillendirdikleri [67] bağlamsalcı yaklaşımla ele alınan çalışmaların bulgularındandir.

Orman ürünleri sanayinde bağlamsalcı bakış açısıyla yapılan çalışmalardan biri Sonnenfeld [68]'dir. $\mathrm{Bu}$ çalışmada rekabet hukukuna aykırı bir şekilde fiyat tespiti suçunu işleyen Amerikan karton sanayi firmaları ele alınarak, yöneticilerin bu suça iliş̧kin algıları araştırılmıştır. Bu araştırma Dearborn ve Simon [69]'ın algısal yanlılı̆̆ın kaynağı olarak fonksiyonel rol yanlılığını gösterdikleri çalışmasına dayandırılmıştır. Fonksiyonel yanlılık uyumsuzluğu azaltmanın bir sonucudur. Uyumsuzluğu azaltma ise bilişsel tutarlılık ilkesine dayanmakta olup, insanların önceki anlayışlarını destekler vaziyette yeni çevresel olayları yorumlama eğilimine gönderme yapmaktadır. İşletmelerde farklı departmanlarda görev alan yöneticilerin farklı beklentilerinin olması bu sebeple gayet doğaldır.

Karton firmalarının dördündeki 12 üst düzey yönetici ile 9 departman yöneticisine, firmalarının fiyat tespiti gizli anlaşmasına dahil olmalarını açıklamaları istenmiştir. Sonuçlara göre üst düzey yöneticiler, ortadaki suçu piyasa şartlarına veya diğer dışsal faktörlere değinmeden bireylerin ihlal edici eylemlerinde görmeye meyletmişlerdir. İhlal eden bireylerin başka suçlara bulaşmalarını önlemek amacıyla cezalandırılması gerektiği düşünülmektedir. Yasalara uyumu artırmaya yardım adına; çalışan seçiminde gözetim, ödüllerin sıklaştırılması ve politikaların açıklığa kavuşturulması gibi araçlar gösterilmiştir. Diğer taraftan departman yöneticileri ise adaleti tesis etmede başarısız olunduğunu düşünmektedirler. Onlara göre birçok vicdanlı insan hak etmedikleri halde acı çekmiştir çünkü yakalananlar onlar olmuştur. Bu yönetici grubuna göre mahkûmiyetler etik dışı bir eylemden ziyade zor iş koşulları ve orman ürünleri sanayindeki siyasi güç eksikliğini göstermektedir. Bu nedenle de departman yöneticileri piyasada daha fazla kontrol elde etmek için işletme stratejilerinde değişikliğe gidilmesini düşünmekte, bu yüzden de dışsal baskılara daha az duyarlı görünmektedirler.

Bir diğer bağlamsalcı çalışmada orman ürünleri sanayindeki üst yönetim takımlarının, uyguladıkları ve rakiplerinin uyguladıkları stratejileri nasıl algıladıkları araştırılmıştır [70]. Bu çalışmada Miles ve Snow [71] tarafindan tarif edilen atılganlar, savunmacılar, analizciler ve tepkiciler olmak üzere dört stratejik yönelim kullanılmıştır. Atılganlar agresif pazar ve ürün geliştirmeye önem verirler ve esas olarak yeni pazar firsatları yaratmak için rekabet ederler. Savunmacılar sanayi dallarındaki niş pazarları kontrol etmeye çalışır ve fiyat, kalite, teslimat ve ürün hizmeti için çalışırlar. Analizciler atılganlara göre daha az ve daha küçük pazar büyütme meyli gösterirler; savunmacılara göre ise durağanlık ve verimliliğe daha az bağlllık gösterirler. Tepkiciler ise stratejilerinden firsatçı sapmalara kalkışırlar ve dikkate aldıkları konulara eşlik eden bir strateji asla geliştirmezler. Falkenberg ve Gronhaug [70] Fortune 500 listesindeki yedi orman ürünleri firmasına yaptıkları mülakatlar sonucunda, üst yönetim takımlarındaki yöneticilerin uygulanan stratejilerle ilgili algılarının büyük oranda farklılıklar gösterdiğini saptamışlardır. Örneğin yöneticilerin $\% 75$ 'i kendilerini analizci olarak nitelemesine rağmen, rakiplerinin \%50'sinin analizci olduğu değerlendirmesinde bulunmuştur. Hatta hiçbir yönetici firmasını tepkici olarak değerlendirmezken; rakiplerini $\% 40$ oranında tepkici olarak algılamaktadırlar. Bu çalışmanın diğer önemli sonucu ise yöneticilerin dikkatlerini rakiplerine veya diğer dışsal faktörlere yöneltmektense içsel faaliyetlere yönelttikleridir.

Kültürü bağlamsalcı bir perspektifle rekabet avantajına eklemleyen Fiol [72], orman ürünleri firmalarının rekabet avantajı yakalamak adına kültürel değişimi nasıl kullandıklarını ortaya 
koymuştur. Rekabet avantajı için Barney [73]'in önerdiği değerli, nadir, eksik taklit edilebilen ve ikame edilemeyen boyutlarına sahip modeli kullanmıştır. Kültürel değişimi ilk başta mevcut davranışların değiştirilmesi veya yeni davranışların eklenmesi şeklinde ele almıştır. Davranışların değiştirilmesinin kültürel değişime ancak ve ancak davranış-kültür arayüzünün güçlü yöneticiler tarafından kontrolü sağlanırsa yol açacağını ifade etmiştir. Ama yine de bu yollu bir kültürel değişim sürdürülebilir rekabet avantajı getirmeyecektir çünkü bu değişim rakipler tarafindan kolaylıkla taklit edilebilir özelliktedir. Buna ek olarak yeni davranış şablonlarının eklenmesinin kültürel değişime yol açması bazı koşullara bağlıdır. Bu eklemeler, orijinal kültürden ayrı olarak doğmasına izin verilen ayrı bir kültüre sahip özerk birimlerde veya departmanlarda kümelenirse değişime yol açabilecektir. Ancak bu tür bir kültürel değişim de kolaylıkla taklit edilebilir olmasından dolayı sürdürülebilir değildir. Fiol [72]'a göre orman ürünleri firmalarındaki kültürel değişim yalnızca yenilenme şeklinde sürdürülebilir rekabet avantajı sağlar. Bunun için yeni davranışları firmanın geleneksel değerlerinden ayrıştırmak ve yeni bağlamsal anlamları bu geleneksel değerlere bağlamak gerekmektedir. Bu çalışmanın bir diğer sonucu orman ürünleri firmalarındaki yöneticilerin nedensel anlayışlarını veya nedensel iddialarını değiştirme gereksinimlerini çok hızlı bir şekilde fark etmelerine rağmen (bunun bir nedeni de hızlı değişen iş çevrelerinde yer almalarıdır) ilgili firmalardaki kimlik haritalarının değişmeden kaldığıdır. Özgönderim şeklinde ortaya çıkan sabit bir çıpa sebebiyle, bu firmalar tanımladıkları nedensel değişikliklere dair eyleme geçememektedirler.

Bağlamı odak noktası yapan bir diğer çalışmada Valentin [74], bir orman ürünleri firmasının uyguladığı rekabet stratejisinin yıkıcı sonuçlarını yorumlamacı bir anlayışla ele almıştır. Bu firmanın ahşap yapı elemanları dağıtım birimini kurmasını, kısa süre içinde beş katı büyütmesini, konut piyasasının daralması sonucunda küçülmeye giderek kilit roldeki personelinin neredeyse tamamını işten çıkarmasını ve sonunda bütün mağazalarını satmasını/kapatmasını incelemiştir. Valentin [74] bu orman ürünleri firmasının örgüt içi dinamiklerini incelerken, bağlamsalcı okulun önemli çalışmalarından olan Child ve Smith [75] ile Pettigrew [76, 77]'den önemli ölçüde faydalanmıştır. Çalışma sonucunda örgütsel ve davranışsal karar teorilerinin yapılan stratejik hataları anlamayı kolaylaştırdığı ve geçmiş başarılar ile ideolojik katılıkların firma içindeki işlevsiz atalet ve zihniyetleri besleyebildiği gösterilmiştir.

\section{SONUC VE ÖNERILER}

$\mathrm{Bu}$ çalışmada stratejik yönetimin son yıllarda gitgide daha fazla meşruluk kazanan bir alt alanı olan davranışsal strateji irdelenmiş ve orman ürünleri sanayi kapsamında yapılan çalışmalar incelenmiştir. İlk etapta yalnızca bilişsel ve sosyal psikoloji teorilerini stratejik yönetime uygulamayı benimseyen davranışsal strateji için son zamanlarda sosyolojik ve politik süreçlerin de tavsiye ve dâhil edildiği görülmüştür. $\mathrm{Bu}$ yönelimin davranışsal stratejiye daha sağlam bir yapı kazandırması muhtemel görülmektedir.

Powel, Lovallo ve Fox [6]'un sınıflandırdığı şekliyle indirgemeci, çoğulcu ve bağlamsalcı bakış açılarıyla hazırlanan bu çalışmada, davranışsal strateji akımının orman ürünleri sanayinde oldukça yeni olduğu sonucuna ulaşılabilir. İndirgemeci yaklaşım açısından aşırı güven, kazananın laneti ve artan bağl1lık şeklinde ortaya konan orman ürünleri sanayi firmalarındaki bilişsel yanlılık araştırmaları bir adım ileriye götürülüp başka bilişsel yanlılık ve kestirme yolların stratejik kararlarda olup olmadığı araştırılabilir. Ayrıca bilinen bu bilişsel yanlılıkların sektöre özgü yanları ve mekanizmaları da psikoloji temelli önemli bir bağlamsal çalışma olabilir.

Yöneticiler karar ve risk teorisinin belirttiği şekilde riski algılamamakta ve risk almamaktadırlar [78]. Sektördeki yöneticilerin karar verirlerken ki risk alg1 ve yönelimleri de çalış1labilecek önemli konulardandir.

Birçok kararda dinamik tutarsızlık (veya zamansal tutarsızlık) olgusunun olduğu, davranışsal ekonominin öteden beri önemli tespitidir [79]. Orman ürünleri sanayi yöneticilerinin zaman içinde 
farklı benliklerle farklı kararlar alıp almadıkları ve yapılan tercihlerin değişme mekanizmaları açıklama bekleyen konulardandır.

Bütün bunların yanında ve nörobilimsel gelişmeler ışığında araştırmacıların fayda sağlayabileceği yeni yöntemler de ortaya çıkmıştır. Nöroekonomi [80] ve nörostrateji [81] ekonomi ve stratejik yönetimdeki davranışsal çalışmaların tamamlayıcısı olarak görülmektedir. Orman ürünleri sanayi firmalarındaki üst yönetim takımlarının nasıl karar aldıkları, nelere dikkat gösterdikleri, araştırmakullanma (exploration-exploitation) seçeneklerinden hangisinin uygun olduğu, kurumsal ve rekabet stratejilerin nasıl tercih edildiği nörobilimsel yöntemlerin açıklık getireceği alanlardan bazılarıdır.

Üst kademe teorisinden beslenen üst yönetim takımları çalışmaları orman ürünleri sanayinde görülen çoğulcu okul çalışmalarıdır. Sektördeki firmaların üst yönetim takımlarının oluşturulma süreçleri ile davranışsal bütünleşme, yönetsel yeti gibi olguların ne düzeyde olduğu çalışılması muhtemel konulardandır. Ayrıca yöneticilerde görülen patolojik ve nevrotik durumlar ile örgütsel performans arasındaki ilişki de gösterilmeyi beklemektedir.

Üst yönetim takımlarına ek olarak örgütsel öğrenme esnasında gerçekleşen işlevsizlikler, performans hedefleri belirlenirken tutulan arzu düzeyleri, stratejik yönetimin bütün aşamalarında görülebilecek firma ile çalışan özdeşleşmesinin çok yönlü sonuçları, orman ürünleri işletmelerinde ele alınabilecek konulardandir.

Yöneticilerin stratejik konularla ilgili algıları orman ürünleri sanayinde en fazla irdelenen bağlamsalcı davranışsal strateji konuları olarak görülmektedir. Bununla ilgili olarak yöneticilerin dış çevrede meydana gelen ve firma için stratejik önem taşıyan konuları tehdit-firsat ekseninde nasıl çerçeveledikleri ve anlam yaratma sürecinin etkileri ele alınabilecek konular arasında gösterilebilir.

Alınan kararların mı yoksa ortaya konulan eylemlerin mi rasyonel olması gerektiği önemli tartışma konularındandır [64]. Bazen irrasyonel kararlardan rasyonel eylemler doğabilmektedir. Bu olguya yönelik olarak orman ürünleri firmalarında stratejik kararların nasıl eyleme dönüştüğü ve amaçlanan ile ortaya çıkan stratejiler arasındaki farkın boyutu da ilgi çekebilecek araştırma konularındandır.

Bilindiği üzere stratejik yönetim süreçlerinin çoğunda stratejik bilinç, düşünme, anlama, değerlendirme, karar verme gibi zihinsel süreçler yer almaktadır [82]. Bu nedenle orman ürünleri sanayinde firmalar arasındaki bilişsel rekabet durumu güzel bir betimsel çalışma olabilecektir. Firmaların rakip tanımlamalarındaki zihinsel modelleri ve kullanılan dil ve işaretler de bu kapsamda çalışma konusu yapılabilir.

\section{KAYNAKLAR}

[1] H. Ülgen ve K. S. Mirze, İsletmelerde Stratejik Yönetim, 5. bask1, İstanbul, Türkiye: Beta Basım Yayım Dağıtım, 2010.

[2] R. Nag, D. C. Hambrick and M. J. Chen, "What is strategic management, really? Inductive derivation of a consensus definition of the field," Strateg. Manag. J., vol. 28, no. 9, pp. 935-955, 2007.

[3] J. S. Bain, Barriers to New Competition: Their Character and Consequences In Manufacturing Industries, Cambridge, MA: Harvard University Press, 1956.

[4] E. T. Penrose, The Theory Of The Growth Of The Firm. Oxford, UK: Oxford University Press, 1959.

[5] J. A. Schumpeter, The Theory Of Economic Development: An Inquiry Into Profits, Capital, Credit, Interest, And The Business Cycle, Piscataway, NJ: Transaction Books, 1934. 
[6] T. C. Powell, D. Lovallo and C. R. Fox, "Behavioral strategy," Strateg. Manag. J., vol. 32, no.13, pp. 1369-1386, 2011.

[7] P. Bromiley and D. Rau, "How would behavioral strategy scholarship lead to prescription?," J. Bus. Econ., vol. 84, no. 1, pp. 5-25, 2014.

[8] G. Gavetti, D. A. Levinthal and W. Ocasio, "Neo-carnegie: the carnegie school's past, present, and reconstructing for the future," Organ. Sci., vol. 18, no. 3, pp. 523-536, 2007.

[9] H. Serin, M. Durgun ve S. Durgun, "James g. march: yönetim ve örgüt çalışmalarında örnek bir figür," Sosyal, Beşeri ve İdari Bilimler-4 Alanında Yeni Ufuklar, Ankara, Türkiye: Gece Kitaplığı, 2019, böl. 2, ss. 29-50.

[10] M. Augier, C. Fang ve V. P. Rindova, "Introduction-behavioral strategy: a quick account," in Behavioral Strategy in Perspective (Advances in Strategic Management), vol. 39, Bingley, UK: Emerald Publishing Limited, 2018, ch. 1, pp. 1-10.

[11] D. C. Hambrick and P. A. Mason, "Upper echelons: the organization as a reflection of its top managers," Acad. Manag. Rev., vol. 9, no. 2, pp. 193-206, 1984.

[12] R. M. Cyert and J. G. March, A Behavioral Theory of the Firm, Englewood Cliffs, NJ: Prentice Hall, 1963.

[13] R. R. Nelson and S. G. Winter, An Evolutionary Theory of Economic Change, Cambridge, MA: Harvard University Press, 1982.

[14] D. A. Levinthal, “Adaptation on rugged landscapes," Manag. Sci., vol. 43, no. 7, pp. 934-950, 1997.

[15] J. G. March, "Rationality, foolishness, and adaptive intelligence," Strateg. Manag. J., vol. 27, no. 3, pp. 201-214, 2006.

[16] S. E. Jackson and J. E. Dutton, "Discerning threats and opportunities," Adm. Sci. Q., vol. 33, no. 3 , pp. $370-387,1988$.

[17] J. F. Porac and H. Thomas, "Taxonomic mental models in competitor definition," Acad. Manag. Rev., vol. 15, no. 2, pp. 224-240, 1990.

[18] C. K. Prahalad and R. A. Bettis, "The dominant logic: a new linkage between diversity and performance,” Strateg. Manag. J., vol. 7, no. 6, pp. 485-501, 1986.

[19] G. Gavetti, "Toward a behavioral theory of strategy," Organ. Sci,, vol. 23, no. 1, pp. 267-285, 2012.

[20] S. G. Winter, "Purpose and progress in the theory of strategy: comments on gavetti," Organ. Sci., vol. 23, no. 1, pp. 288-297, 2012.

[21] D. A. Levinthal, "A behavioral approach to strategy-what's the alternative?," Strateg. Manag. J., vol. 32, no. 13, pp. 1517-1523, 2011.

[22] J. G. March, "Some thoughts on the development of disciplines, with particular attention to behavioral strategy," in Behavioral Strategy in Perspective (Advances in Strategic Management), vol. 39, Bingley, UK: Emerald Publishing Limited, 2018, ch. 2, pp. 13-21. 
[23] D. Lovallo and O. Sibony, "The case for behavioral strategy," in McKinsey Quarterly, vol. 2, no. 1, pp. 30-43, 2010.

[24] H. R. Greve, "Microfoundations of management: behavioral strategies and levels of rationality in organizational action," Acad. Manag. Perspect., vol. 27, no. 2, pp. 103-119, 2013.

[25] O. Sibony, D. Lovallo and T. C. Powell, "Behavioral strategy and the strategic decision architecture of the firm," Calif. Manag. Rev., vol. 59, no. 3, pp. 5-21, 2017.

[26] D. C. Hambrick and C. Crossland, "A strategy for behavioral strategy: appraisal of small, midsize, and large tent conceptions of this embryonic community," in Behavioral Strategy in Perspective (Advances in Strategic Management), vol. 39, Bingley, United Kingdom: Emerald Publishing Limited, 2018, ch. 3, pp. 23-39.

[27] A. H. Aydın, S. Durgun ve M. Durgun, "Davranışsal kamu yönetimi: yöntemsel ve teorik düzlemlerde bir inceleme,” J. Acad. Value Stud., c. 5, s. 4, ss. 528-542, 2019.

[28] T. C. Powell, "Strategy as diligence: putting behavioral strategy into practice," Calif. Manag. Rev., vol. 59, no. 3, pp. 162-190, 2017.

[29] M. Augier and N. Dew, "A behavioral (simonian) perspective on (behavioral) strategic management research," Behavioral Strategy in Perspective (Advances in Strategic Management), vol. 39, Bingley, UK: Emerald Publishing Limited, 2018, ch. 5, pp. 51-67.

[30] J. D. Westphal, "Decoupling and intergroup dynamics in behavioral strategy, and a more integrative alternative," Behavioral Strategy in Perspective (Advances in Strategic Management, Vol. 39), Bingley, United Kingdom: Emerald Publishing Limited, 2018, ch. 4, pp. 41-50.

[31] W. Doniger, "Reductionism," in Merriam-Webster's Encyclopedia of World Religions, Springfield, MA: Merriam-Webster, 1999, pp. 911.

[32] M. Ruse, "Reductionism," in The Oxford Companion to Philosophy, Oxford, UK: Oxford University Press, 2005, pp. 793.

[33] R. L. Ackoff, Redesigning the Future: A Systems Approach to Societal Problems, Hoboken, NJ: John Wiley \& Sons, 1974.

[34] M. Proudfoot and A. R. Lacey, The Routledge Dictionary of Philosophy. 4th ed., Abingdon, United Kingdom: Routledge, 2009, pp. 343.

[35] P. E. Tetlock, "Some thoughts on fourth-generational models of social cognition," Psychol. Inq., vol. 1, no. 3, pp. 212-214, 1990.

[36] R. Roll, "The hubris hypothesis of corporate takeovers," J. Bus., vol. 59, no. 2, pp. 197-216, 1986.

[37] C. Camerer and D. Lovallo, "Overconfidence and excess entry: an experimental approach," Am. Econ. Rev., vol. 89, no. 1, pp. 306-318, 1999.

[38] S. Hall, D. Lovallo and R. Musters, "How to put your money where your strategy is," McKinsey Quarterly, no. March, pp. 1-12, 2012.

[39] P. Rosenzweig, The Halo Effect:... And the Eight Other Business Delusions that Deceive Managers, New York, NY: Simon and Schuster, 2007. 
[40] G. Filbeck, R. F. Gorman and D. C. Preece, "Behavioral aspects of the intra-industry capital structure decision," J. Financ. Strateg. Decis., vol. 9, no. 2, pp. 55-67, 1996.

[41] J. Patel, R. Zeckhauser and D. Hendricks, "The rationality struggle: illustrations from financial markets," Am. Econ. Rev., vol. 81, no. 2, pp. 232-236, 1991.

[42] G. A. Quattrone and A. Tversky, "Contrasting rational and psychological analyses of political choice,” Am. Political Sci. Rev., vol. 82, no. 3, pp. 719-736, 1988.

[43] J. H. Michael and C. D. Ray, "Management decisions in the forest products industry: where good companies go astray," Forest Prod J, vol. 58, no.10, pp. 6-14, 2008.

[44] D. Kahneman, P. Slovic and A. Tversky, Judgment under Uncertainty: Heuristics and Biases, Cambridge, United Kingdom: Cambridge University Press, 1982.

[45] E. J. Zajac and M. H. Bazerman, "Blind spots in industry and competitor analysis: implications of interfirm (mis) perceptions for strategic decisions," Acad. Manag. Rev., vol. 16, no. 1, pp. 37-56, 1991.

[46] B. M. Staw, "The escalation of commitment to a course of action," Acad. Manag. Rev., vol. 6, no. 4 , pp. 577-587, 1981.

[47] L. D. Parker, "Social and environmental accountability research: a view from the commentary box," Account. Auditing Account. J., vol. 18, no. 6, pp. 842-860, 2005.

[48] A. G. Scherer, "Pluralism and incommensurability in strategic management and organization theory: a problem in search of a solution," Organ., vol. 5, no. 2, pp. 147-168, 1998.

[49] C. Knudsen, "Pluralism, scientific progress, and the structure of organization theory," in The Oxford Handbook of Organization Theory, Oxford, UK: Oxford University Press, 2003, ch.9, pp. 262288.

[50] W. M. Cohen and D. A. Levinthal, "Absorptive capacity: a new perspective on learning and innovation," Adm. Sci. Q., vol. 35, no. 1, pp. 128-152, 1990.

[51] D. J. Terry and V. J. Callan, "In-group bias in response to an organizational merger," in Group Dyn. Theory Res. Pract., vol. 2, no. 2, pp. 67-81, 1998.

[52] G. P. Huber and K. Lewis, "Cross-understanding: implications for group cognition and performance," Acad. Manag. Rev., vol. 35, no. 1, pp. 6-26, 2010.

[53] M. F. Wiersema and K. A. Bantel, "Top management team demography and corporate strategic change," Acad. Manag. J., vol. 35, no. 1, pp. 91-121, 1992.

[54] H. Mintzberg, The Structuring Of Organizations, Englewood Cliffs, NJ: Prentice Hall, 1979.

[55] A. P. Jacquemin and C. H. Berry, "Entropy measure of diversification and corporate growth," J. Ind. Econ., vol. 27, no. 4, pp. 359-369, 1979.

[56] K. Palepu, "Diversification strategy, profit performance and the entropy measure," Strateg. Manag. J., vol. 6, no. 3, pp. 239-255, 1985.

[57] A. L. Iaquinto and J. W. Fredrickson, "Top management team agreement about the strategic decision process: a test of some of its determinants and consequences," Strateg. Manag. J., vol. 18, no. 1, pp. 63-75, 1997. 
[58] P. Drucker, The Practice Of Management, Abingdon, UK: Routledge, 1954.

[59] C. R. Berger, "Beyond initial interaction: uncertainty, understanding, and the development of interpersonal relationships," in Language and Social Psychology, Baltimore, MD: University Park Press, 1979, ch. 6, pp. 122-144.

[60] R. L. Falcione and C. E. Wilson, "Socialization processes in organizations," in Handbook Of Organizational Communication, Santa Barbara, CA: Praeger Publishers, 1988, ch. 11, pp. 301-338.

[61] F. M. Jablin, "Organizational communication: an assimilation approach," Social Cognition and Communication, Beverly Hills, CA: Sage, 1982, ch. 9, pp. 255-286.

[62] J. W. Fredrickson, "The comprehensiveness of strategic decision processes: extension, observations, future directions," Acad. Manag. J., vol. 27, no. 3, pp. 445-466, 1984.

[63] K. E. Weick, "Enacted sensemaking in crisis situations," J. Manag. Stud., vol. 25, no. 4, pp. 305-317, 1988.

[64] N. Brunsson, "The irrationality of action and action rationality: decisions, ideologies and organizational actions," J. Manag. Stud., vol. 19, no. 1, pp. 29-44, 1982.

[65] W. H. Starbuck and F. J. Milliken, "Challenger: fine-tuning the odds until something breaks," J. Manag. Stud., vol. 25, no. 4, pp. 319-340, 1988.

[66] E. Abrahamson, "Managerial fads and fashions: the diffusion and rejection of innovations," Acad. Manag. Rev., vol. 16, no. 3, pp. 586-612, 1991.

[67] J. E. Dutton and J. M. Dukerich, "Keeping an eye on the mirror: image and identity in organizational adaptation," Acad. Manag. J., vol. 34, no. 3, pp. 517-554, 1991.

[68] J. Sonnenfeld, "Executive apologies for price fixing: role biased perceptions of causality," Acad. Manag. J., vol. 24, no.1, pp. 192-198, 1981.

[69] D. C. Dearborn and H. A. Simon, "Selective perception: a note on the departmental identifications of executives," Sociometry, vol. 21, no. 2, pp. 140-144, 1958.

[70] J. S. Falkenberg ve K. Gronhaug, "Managerial perceptions of strategy and strategy change," Eur. Manag. J., vol. 7, no. 2, pp. 209-217, 1989.

[71] R. Miles and C. Snow, Organizational Strategy, Structure, and Process, New York, NY: Mcgraw-Hill Book Company, 1978.

[72] C. M. Fiol, "Managing culture as a competitive resource: an identity-based view of sustainable competitive advantage," J Manag., vol. 17, no. 1, pp. 191-211, 1991.

[73] J. B. Barney, "Organizational culture: can it be a source of sustained competitive advantage?," Acad. Manag. Rev., vol. 11, no. 3, pp. 656-665, 1986.

[74] E. K. Valentin, "Anatomy of a fatal business strategy," J. Manag. Stud., vol. 31, no. 3, pp. 359-382, 1994.

[75] J. Child and C. Smith, "The context and process of organizational transformation-cadbury limited in its sector," J. Manag. Stud., vol. 24, no. 6, pp. 565-593, 1987. 
[76] A. M. Pettigrew, The Awakening Giant: Continuity and Change in Imperial Chemical Industries, Abingdon, United Kingdom: Routledge, 1985.

[77] A. M. Pettigrew, "Context and action in the transformation of the firm," J Manag. Stud., vol. 24, no. 6, pp. 649-670, 1987.

[78] J. G. March and Z. Shapira, "Managerial perspectives on risk and risk taking," Manag. Sci., vol. 33, no. 11, pp. 1404-1418, 1987.

[79] G. Loewenstein and D. Prelec, "Anomalies in intertemporal choice: evidence and an interpretation," Q. J. Econ., vol. 107, no. 2, pp. 573-597, 1992.

[80] C. Camerer, G. Loewenstein and D. Prelec, "Neuroeconomics: how neuroscience can inform economics," J. Econ. Lit., vol. 43, no. 1, pp. 9-64, 2005.

[81] T. C. Powell, "Neurostrategy," Strateg. Manag. J., vol. 32, no. 13, pp. 1484-1499, 2011.

[82] H. Serin ve M. Durgun, "İşletmelerde yenilikçi yaklaşım olarak stratejik yönetim süreci," Ziraat, Orman ve Su Ürünleri Alanında Yenilikçi Yaklaşımlar, Ankara, Türkiye: Gece Kitaplığı, 2018, böl. 3, ss. 23-42. 